\title{
THE SIGNIFICANCE OF CONCENTRATION AND DILUTION TESTS IN BRIGHT'S DISEASE
}

\author{
By ALF S. ALVING AND DONALD D. VAN SLYKE \\ (From the Hospital of the Rockefeller Institute for Medical Research, \\ New York City)
}

(Received for publication August 6, 1934)

The first quantitative evidence that nephritis diminishes the ability to excrete urine of either high concentration or high dilution was apparently furnished by Korányi (1899) and his collaborators, Kövesi and RothSchulz (1900), by means of the freezing point method. Regular application to studies of renal function, however, appears to have first begun in Volhard's (1918) clinic, where the "concentration and dilution" test has been in use since about 1908. In this test the renal function is estimated from the ability to excrete a urine of large volume and low specific gravity after drinking 1.5 liter of water (dilution test), and urine of high specific gravity after a subsequent period in which no fluid is drunk (concentration test). Modifications of these tests or their combination have been made by various authors. They have been reviewed by Pratt (1926) (with his own observations on 58 patients), by Mosenthal (1930), by Lashmet and Newburgh (1930), and with especial completeness by Volhard and Becher (1929). The simplicity of these tests, and their consequent wide application, render it desirable to define as exactly as possible the meaning of their results.

In order to obtain information for this purpose we have made graphic statistical comparisons of results of concentration tests with results of the urea clearance test, the clinical significance of which has previously been established (Van Slyke, Stillman, Möller, et al. $(1930)^{1}$ ). We have furthermore carried out prolonged observations with concentration tests and urea clearance combined on individual patients with the different types of Bright's disease, so that the prognostic significance of the tests could be deduced from the clinical outcome.

While our studies have been in progress, other data comparing results of concentration and dilution tests with results of the urea clearance test have been published by Ong (1932) from Snapper's clinic, and by Bruger and Mosenthal (1932).

1 The terms, "standard blood urea clearance" and "maximum blood urea clearance" used in expressing the urea excreting efficiency of the kidneys, have been defined by Möller, McIntosh and Van Slyke (1928). 


\section{METHODS}

Two forms of the concentration test (Addis and Shevky (1922) ; Lashmet and Newburgh (1930)) and one of the combined concentration and dilution test (Lundsgaard (1920)) have been used in this clinic for comparison with the blood urea clearance. In addition to our results with these tests we have charted the data of Ong (1932) and of Bruger and Mosenthal (1932). The different concentration and dilution tests, as used by the writers and the above authors, were applied as follows.

\section{Concentration tests}

The concentration test of Addis and Shevky (1922). The subject abstains from fluids of all sorts from after breakfast on one day until he rises from bed on the morning of the following day. During the last 12 hours of the dry period (from 8 p.m. to 8 a.m.) the urine is collected, and the specific gravity of this specimen is measured. The Addis-Shevky test prescribes no preparatory period on a special diet.

In applying this method to albuminous urines we have subtracted from the observed specific gravity a correction for the effect of the protein, in the manner described below for the Lashmet-Newburgh test. The gravities given in our charts are the corrected values. The urinometer used has been found accurate to within 0.001 .

Addis and Shevky have found that in normal individuals, previously on ordinary diets, the average specific gravity of urine obtained as above described was 1.032 , that 95 per cent of normal subjects on ordinary diets showed values of 1.028 or above, and 100 per cent above 1.026 .

The concentration test of Lashmet and Newburgh (1930). ${ }^{2}$ The subject remains in bed four days, during the first three of which he is on a special diet. The diet consists of 45 grams of protein, 106 grams of fat, and 180 grams of carbohydrate. The sodium chloride intake is from 2 to 3 grams daily, and the fluid 1500 cc. At 6 p.m. on the third day, after the patient has had supper, all intake, both food and fluid, is stopped until noon the following day. All urine is discarded except the specimen obtained from 10 a.m. until 12 noon on the fourth day. The specific gravity of this two-hour urine specimen is determined. We did this by means of small weighing bottles as described by Moore and Van Slyke (1930). When protein was present in significant amounts the observed specific gravity was corrected by subtraction of the increment in gravity due to the protein, as was done by Lashmet and Newburgh (1930). ${ }^{3}$ Their more recent (1932) correction curve corresponds to the equation:

$$
\text { Sp. Gr. correction }=0.003 \times \text { (per cent protein }) \text {. }
$$

Lashmet and Newburgh found that all normal subjects concentrated the urine to 1.026 or above on this regime.

2 Since the completion of this paper Lashmet and Newburgh (1932) have altered their test, omitting the three-day preparatory period, but increasing the period of desiccation to 24 hours.

${ }^{3}$ If the specific gravity of the protein in the urine is not taken into account, there is wider scattering of points in Figure 1. 


\section{Combined concentration and dilution tests}

Lundsgaard's modification of the Volhard tests. Christen Lundsgaard (1920, unpublished) slightly modified for use in this hospital the Volhard concentration and dilution test. Dilution. The subject receives no water after midnight. He voids at 7 a.m., then drinks $1000 \mathrm{cc}$. of water and voids each hour till 11 a.m. Concentration. The concentration test is done on a different day. No water is taken after preceding midnight. A dry meal, consisting of 65 grams toast, 15 grams butter, 100 grams scrambled eggs, 25 grams cream, and 15 to 20 grams jam or jelly, is given at 7:30, and repeated at 10:00 and $11: 40$ a.m. Urine is voided every 2 hours from 7 a.m. to 3 p.m. The specific gravity in normal subjects rises above 1.025, and usually as high as 1.030 .

Rosenberg's (1927) modification of the Volhard tests. Rosenberg added precautions to make certain that the body was in a normal and steady state of hydration. For 2 days before either the concentration or dilution test, which were done on different days, the subject was put on a controlled diet, without unusual variations in salt, and with $1500 \mathrm{cc}$. of water. The weight of the subject was taken during the days before and after the test in order to detect instability in the water balance, due to the invalidating factors mentioned below, or others. For the rest, the technique was essentially that of Volhard, except that in the dilution test only 1000 instead of $1500 \mathrm{cc}$. of water were taken. The urine was collected in half-hour periods for 4 hours after drinking the water. During the next 24 to 48 hours a dry diet was taken, and the urine was collected every hour or two, till its specific gravity reached a maximum. Rosenberg's modification was used by Ong (1932), whose results are discussed later. To judge from comparison of Figure 1 and Figure 4-A the preliminary regime had little influence in making the results more uniform.

Mosenthal's $(1915,1918)$ test based on spontaneous variations in the specific gravity of the day urine and on the volume of the night urine. This is a modification of the Hedinger and Schlayer test (1914). The subject is allowed to follow his own desires concerning intake of food and fluids. Restriction of diet was found by Mosenthal (1918) to be unnecessary. The test depends on the facts that, with ordinary fluid intake, even at a constant rate per hour, the hourly urine volume and specific gravity vary markedly during the day in normal subjects, and that the extent of the variation diminishes in nephritis. The urine is collected in 2-hour periods from 8 a.m. to 8 p.m., and in a 12-hour period from 8 p.m. to 8 a.m. the next morning. The specific gravities of the 2 -hour specimens are measured, and the volume of the 12-hour night specimen. The normal values given in Mosenthal's most recent paper (Bruger and Mosenthal (1932)) are a specific gravity of 1.020 or above in one or more of the 2 -hour specimens, a specific gravity difference of not less than 0.009 between the highest and lowest specimen, and a volume less than $725 \mathrm{cc}$. for the 12 -hour night urine.

\section{ANALYTICAL METHODS}

The urine protein was measured by the method of Shevky and Stafford (1923) as slightly modified by MacKay (Peters and Van Slyke, 1932, II, p. 682).

The methods used in determining and calculating the standard and maximum urea clearances have been described by Möller, McIntosh and Van Slyke (1928). The clearance has been recorded in percentages of 
the mean normal values, which are $54 \mathrm{cc}$. per minute for the "standard" clearance, determined with low urine volumes, and $75 \mathrm{cc}$. for the "maximum " clearance, determined with high urine volumes, with due correction for body size in cases much above or below average adult stature (McIntosh, Möller, and Van Slyke (1928)).

Urea in the blood and urine was determined by the gasometric urease method (Van Slyke (1927)).

Urine total base was determined gasometrically as described for blood by Van Slyke, Hiller, and Berthelsen (1927). The method described by

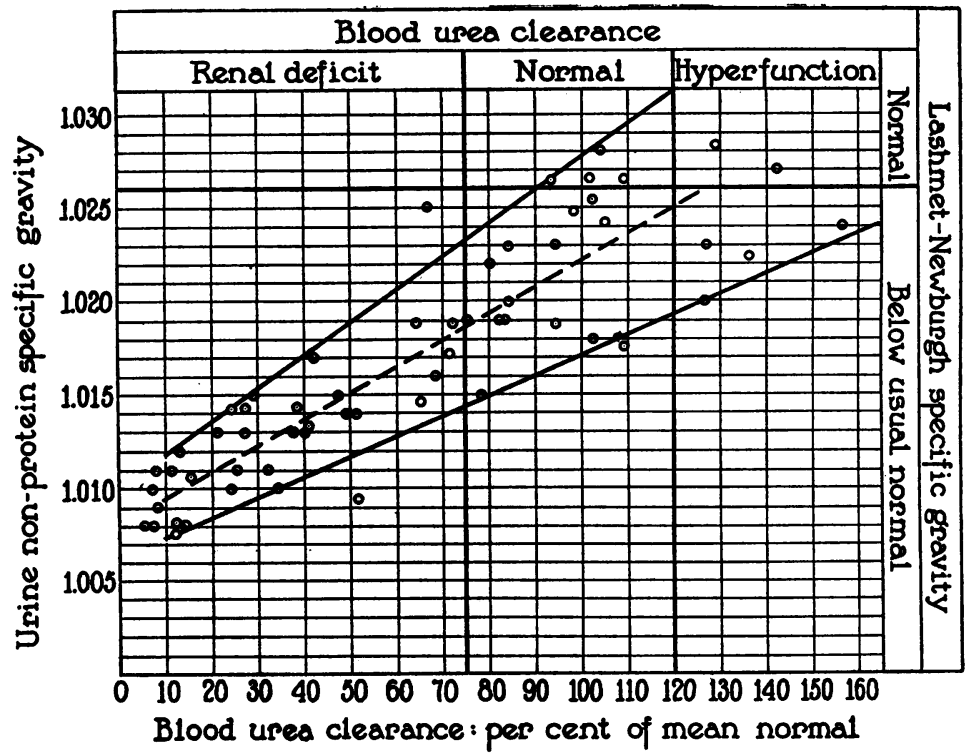

Fig. 1. Lashmet-Newburgh Concentration Test

Each circle represents results of the concentration test and the urea clearance with one subject. The gravities are corrected for the effect of urine proteins. All the subjects were nephritic patients. Hence the presence of low specific gravities in subjects with normal urea clearances.

these authors for serum was applied to urine without change, except in the size of samples used. The total base in urine of different concentrations varies so greatly that it is desirable to vary the samples so that each will contain the amount of base in $1 \mathrm{cc}$. of a 100 to 200 milli-equivalent solution. The size of sample required can be estimated from the nonprotein specific gravity of the urine, as indicated by Figure 14.

\section{RESULTS OF CONCENTRATION TESTS}

Statistical comparison with the urea clearance test

The Lashmet-Newburgh test was compared with the clearance in 39 subjects, and the results are shown in the dot diagram of Figure 1. The 
Addis-Shevky test was performed on the same subjects, and in addition data were available for a number of other patients who had previously been put on the Addis 20-hour dry regime in order to obtain concentrated urine for count of the formed elements (Addis (1925)). The results of the Addis-Shevky 'test are presented in Figure. 2. The results with Lundsgaard's modification of the Volhard test are given in Figure 3, the data of Ong with the Rosenberg modification of Volhard's test are reproduced in Figure 4, and Bruger and Mosenthal's results with the Mosenthal test in Figure 5.

The specific gravity values in the Addis-Shevky and Lashmet-Newburgh tests (Figures 1 and 2), were corrected for the protein present.

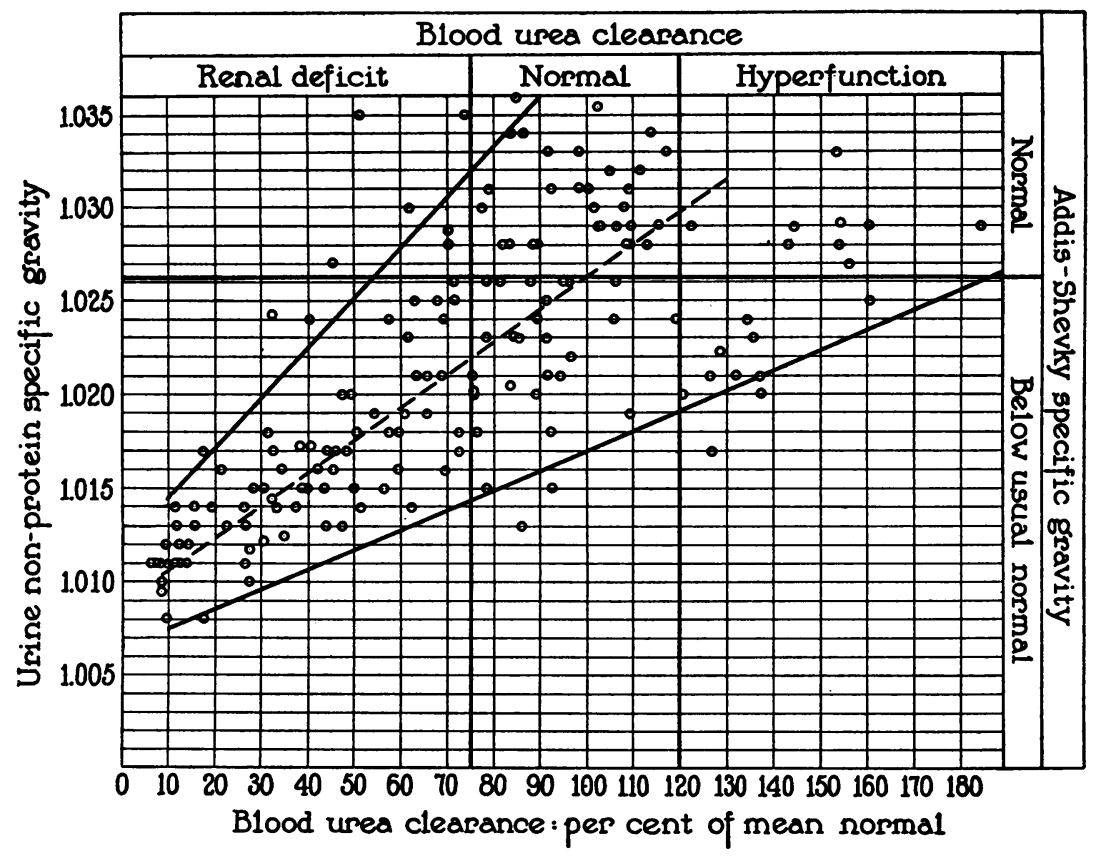

Fig. 2. Addis-Shevky Concentration Test

Each circle represents results with one subject. The gravities are corrected for the effect of urine proteins. All the subjects were nephritic patients. Hence the presence of low specific gravities in subjects with normal urea clearances.

The data from previous authors, presented in Figures 3-A, 4-A, and 5-A, lack this correction, so that the urine specific gravities shown in cases with heavy albuminuria are higher than they would be if corrected. It is probable therefore that in these figures, especially Figure 4-A, some of the cases which show normal specific gravity with subnormal urea clearance, would show subnormal urine gravities and better correlation with the clearance, if the protein correction were applied. 


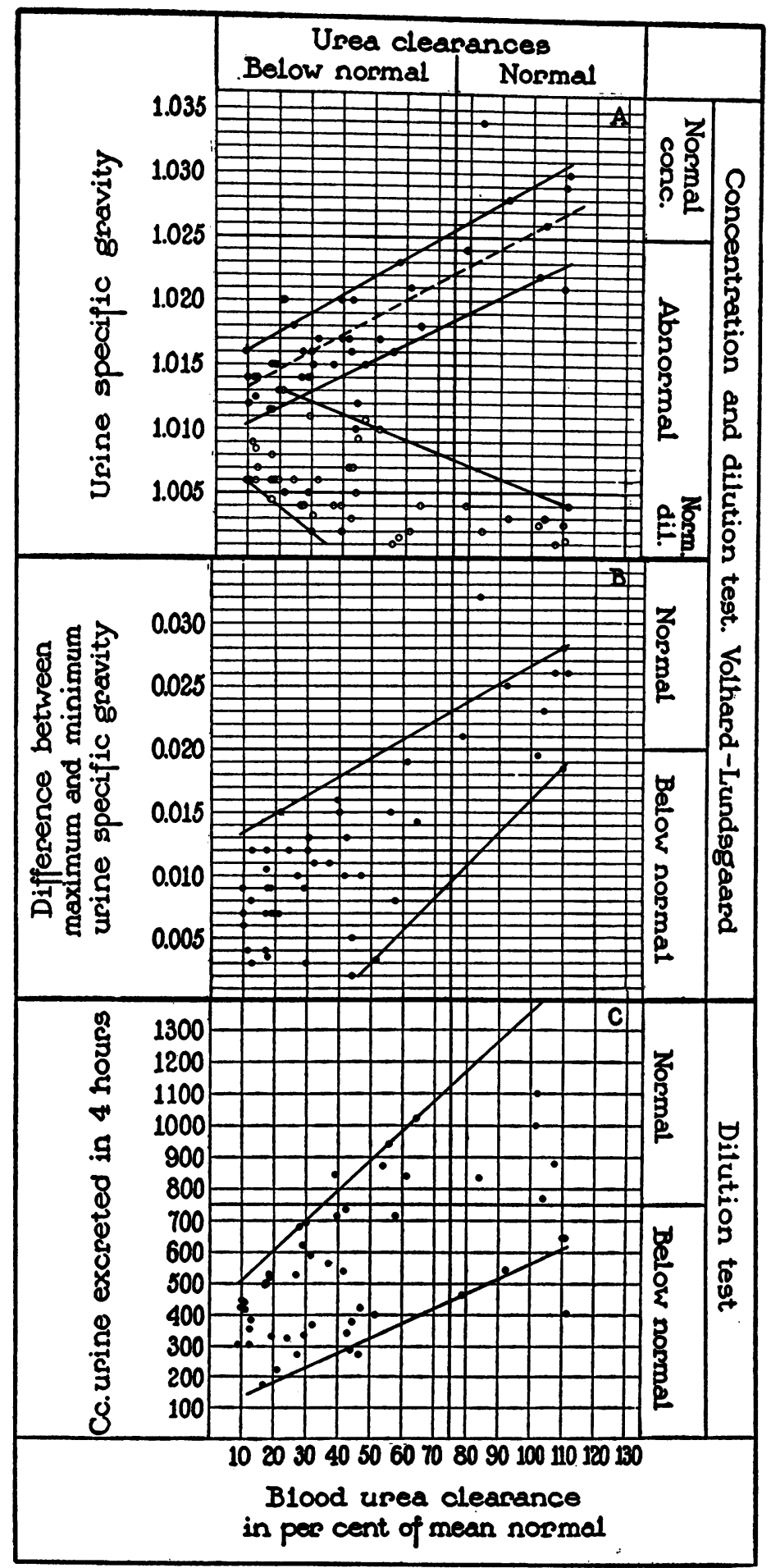

Fig. 3. Volhard-Lundsgaard Concentration and Dilution Test

Each circle represents the blood urea clearance and the result of the concentration or dilution test with one subject. In chart A solid circles represent maximum specific gravities obtained in the concentration test. Hollow circles represent minimum specific gravities obtained in the dilution test. The gravities are not corrected for the effect of urine protein concentration. Data of Lundsgaard (1920) and successors. All the subjects were nephritic patients. 


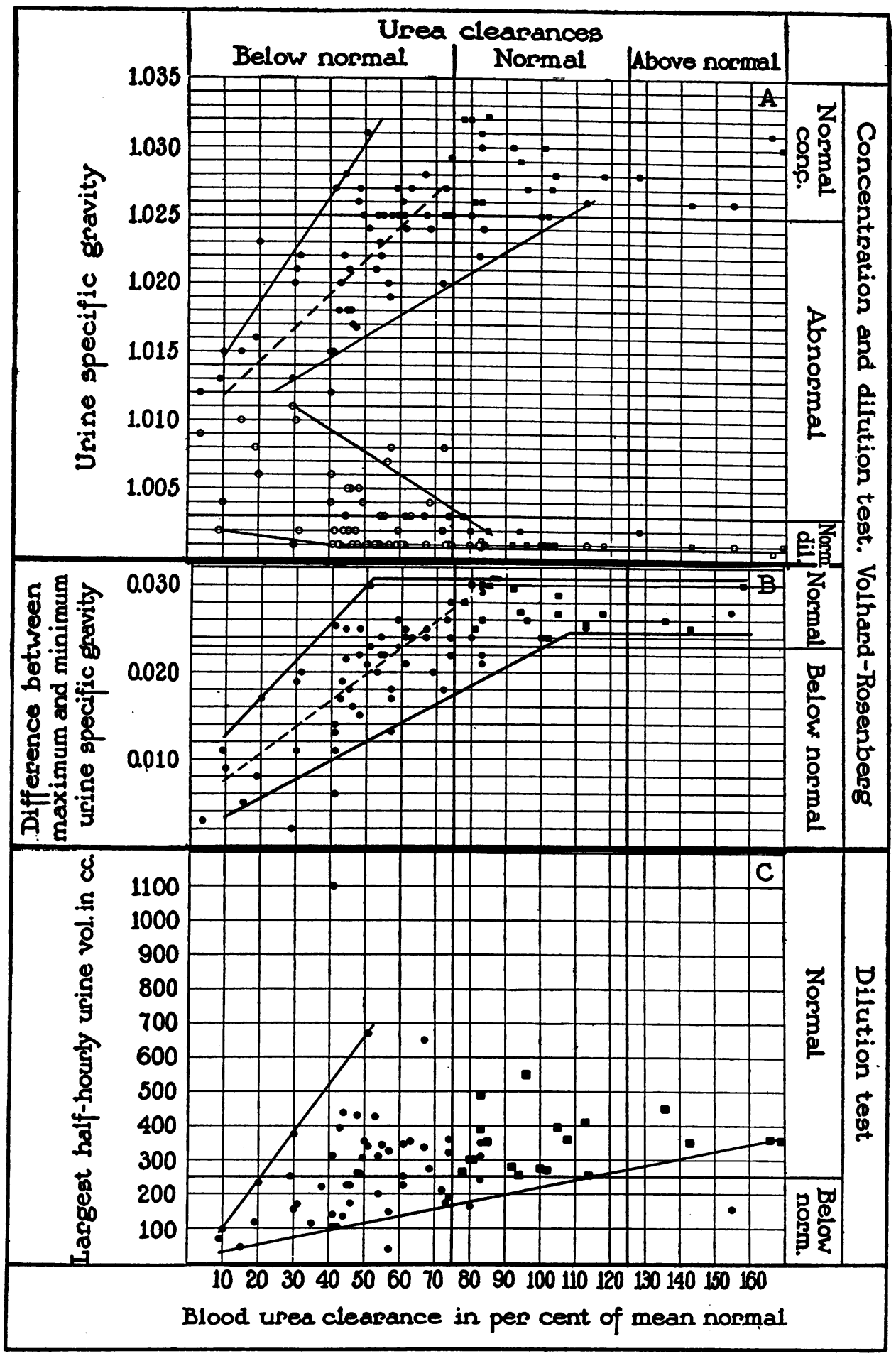

Fig. 4. Ong's Results with Volhard-Rosenberg Concentration and Dilution TEST

Maximum specific gravities, obtained in the concentration test, are represented by solid circles or squares: minimum gravities, obtained in the dilution test, are represented by hollow circles and squares. The gravities are not corrected for the effect of urine protein concentration. Circles represent results in nephritic subjects. Squares represent results in normal subjects. 


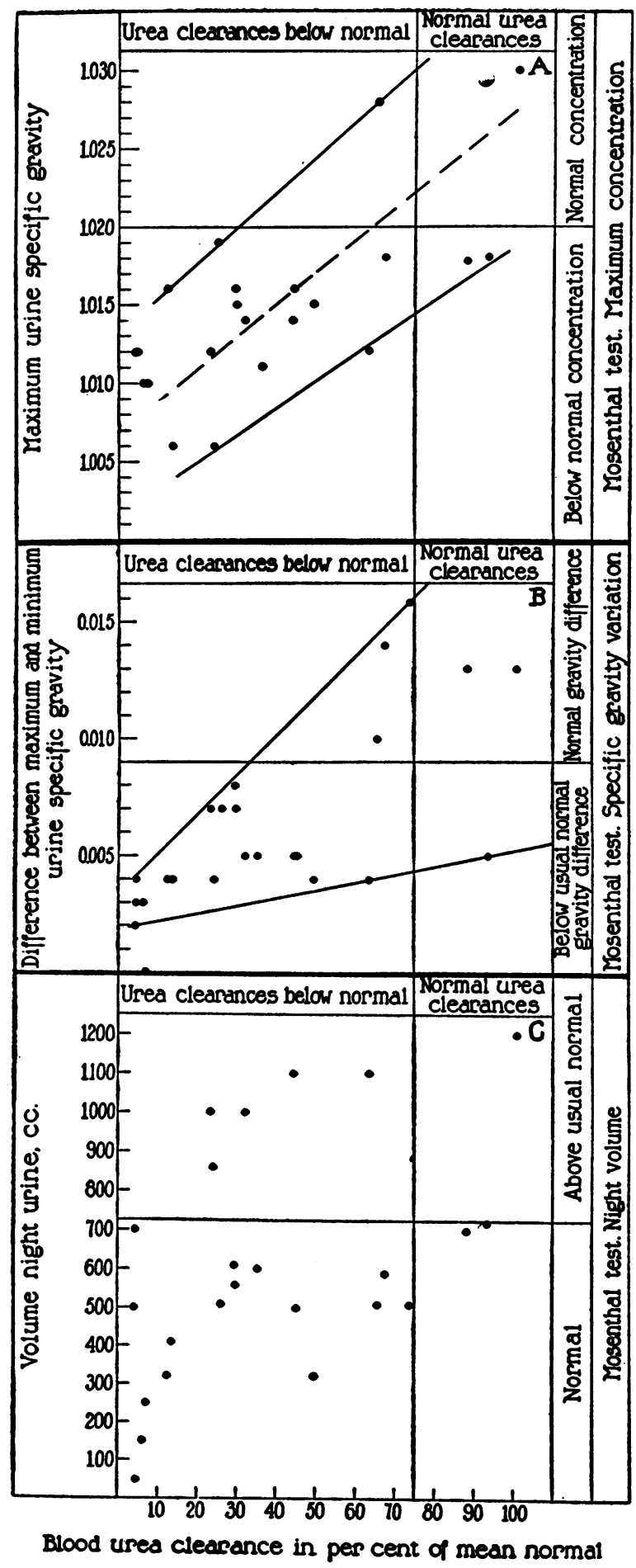

Fig. 5. Results of Bruger and Mosenthal (1932) with the Mosenthal (1918) Spontaneous Concentration and Dilution Test All the subjects were nephritic patients. 
It is obvious from the dot diagrams of Figures 1, 2, 3-A, 4-A, and 5-A, that nephritic patients with normal urea clearances frequently show low specific gravities by the concentration tests. (Normal clearances are encountered with some frequency, in the presence of obvious renal abnormality, in the following conditions : in mild acute nephritis, in the recovery stage of acute nephritis, and in some cases of nephrosis (Van Slyke, Stillman, Möller, et al. (1930)).)

In cases with less than normal urea clearances, the charts show correlation between the fall in clearance and the fall in specific gravity.

In so far as the different tests compare, the relatively narrow area enclosing all but 2 of the points on Figure 1 appears to indicate that the Lashmet-Newburgh concentration test agrees, somewhat more consistently than the other concentration tests, with the urea clearance. Somewhat greater consistency might be expected of the Lashmet-Newburgh test because of the more complete preparation, with the 3-day preliminary regime. However, the 2-day preliminary regime of the Rosenberg test (Figure 4-A) appears to give, with the urea clearance, no obviously closer correlation than the 12-hour preliminary regimes of the Addis-Shevky (Figure 1) or Lundsgaard (Figure 3-A) tests. Mosenthal's test is distinguished from the others in that it involves no preliminary desiccating period at all, and merely measures the maximum specific gravity that occurs spontaneously during a day on unrestricted solid and fluid intakes. The chief effect is that the general level of the specific gravities obtained in the Mosenthal test is lower than in the others, the normal low limit being at 1.020 instead of 1.025 to 1.026 , while the trend of the pathological values is also lower in the Mosenthal test. Aside from this difference, and some apparent loss in sensitivity entailed, the Mosenthal test appears to give results of the same significance as the concentration tests done with regimes of prescribed solid and fluid intake.

In general, Figures 1 to 5 indicate that in nephritic cases with low urea clearance, all the concentration tests yield urine specific gravities tending to fall with diminishing urea clearance until the clearance has fallen to 20 or 30 per cent of normal. The broken slanting line in each chart indicates approximately the mean relationship between clearance and urine specific gravity, while the area enclosed within the two solid slanting lines indicates the extremes of variation that may ordinarily be expected. Thus, in Figure 2, it is apparent that a urine specific gravity of 1.016 in the Addis-Shevky test corresponds on the average to a urea clearance 40 per cent of mean normal, but may coincide with urea clearances anywhere from 16 to 90 per cent of mean normal. That the clearance, in a case with a given urine specific gravity, may occasionally be outside of even such a wide range, is indicated by the presence of a few dots outside the area between the two solid lines. It is evident that a given subnormal 
specific gravity may accompany either a very low urea clearance, or one within the normal range.

More specific information concerning the significance of the concentration tests is yielded by continual observation of individual cases through the different stages of renal disease. The results of such observations will next be considered.

\section{Acute hemorrhagic nephritis 4}

Acute cases with both tests normal throughout. Several cases of transitory acute nephritis with normal urea clearances have been reported by Van Slyke, Stillman, et al. (1930). In Figure 6 are charts ${ }^{5}$ of three cases which throughout the period of observation gave normal results, not only by the urea clearance, but also by the concentration test. The hematuria, proteinuria, and initial edema, however, leave no doubt that each patient passed through an attack of acute nephritis.

4 The nomenclature used to indicate the different types of nephritis is that outlined by Van Slyke, Stillman, Möller, et al. (1930), as developed from Volhard and Fahr, and Addis.

${ }^{5}$ Explanation of Case Charts.

For renal function, hemoglobin in blood, hematuria, plasma proteins, and blood pressure the mean normal is drawn as a base line; the shaded areas between the base line and the points representing observations indicate the degree of deviation above or below the average normal. When the shaded area extends downward from the base line the observed value is below the normal average, and vice versa. Gross hematuria is plotted as columns extending above the 100 million mark.

The brackets at the left of the scales for urea clearance, urine concentration and hematuria indicate the range of normal variability. The normal base line for hemoglobin values varies with the patient's age and sex.

The scales for urine protein and diet are obvious.

The black areas representing edema have the following significance.

Height of black area in quarters of total space

Edema

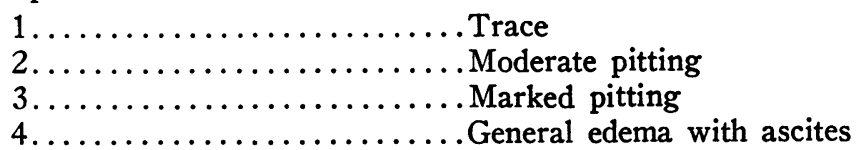

Under fundus changes we chart constriction of the arterioles, arteriolar sclerosis, exudate, retinal hemorrhages, and papilledema. The degree of development of each change is indicated by the proportion of the indicated area on the chart which is blackened; a minimal change is indicated by blackening of $1 / 4$ of the area, and a maximal one by blackening of the entire area.

The vertical spaces which are left unshaded for the entire length of a chart indicate periods during which no observations were made, usually because the patient was out of the hospital.

At the bottom of each chart the number at the left nearest "months" indicates the number of months the disease was noted before the patient entered the hospital. The other numbers in the bottom row indicate months after first admission. 

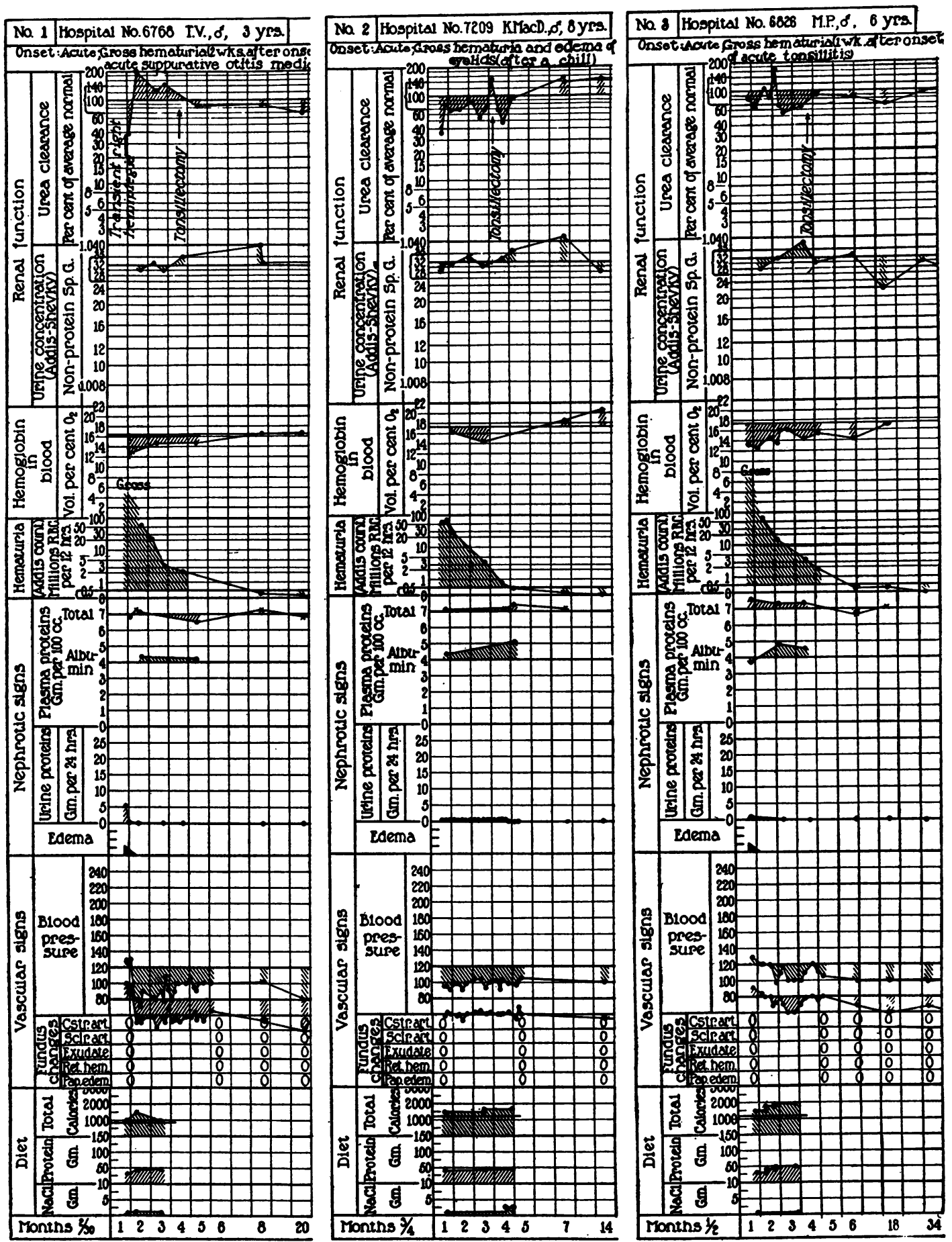

Fig. 6. Three Cases of Transitory Acute Hemorrhagic Nephritis Without Functional Effect on Either Urea Clearance or Concentration Test

See footnote 5 , page 978 , for explanation of case charts. 
Acute cases in which both tests are depressed, with subsequent return of the clearance to normal, while low specific gravity persists for some time longer. In patients recovering from acute nephritis the urea clearance frequently rises to normal level sooner than does the urine specific gravity. This behavior is exemplified by the two cases in Figure 7. Three months after onset of acute nephritis in Case 4 the urea clearance had risen to 80 per cent of average normal, a value well within normal range, while the urine specific gravity in both the Addis-Shevky and the Lashmet-Newburgh tests had risen from 1.010 to 1.012 only as far as 1.019-1.020. In Case 5 the time lag of the concentration test was still more striking. Three months after onset the clearance had returned to normal, while the urine specific gravity by the Addis test still remained at 1.011 to 1.012 , a value frequently found in uremia. Later the urine specific gravities in both cases gradually rose till they were within normal limits.

Usually, as in these two cases, if the specific gravity test in an improving patient fails to reach normal as soon as the urea clearance, it attains normal level a few weeks or months later. In exceptional cases, however, the period during which subnormal concentration tests persist despite normal urea clearance has lasted for several years, as exemplified by Case 7 in Figure 8.

Advantages of observing both tests in acute nephritis. The question arises, whether a low concentration test, persisting after recovery of normal urea clearance and subjective well-being, is significant. Our observations lead us to believe that it is, and that the continuance of low concentration tests indicates the persistence of some renal damage. In most cases during the period when the concentration test lags behind the clearance in regaining normal level, the persistance of hematuria, proteinuria, or other signs indicates that the kidneys are not yet normal (Cases 4 and 11), though occasionally (Case 5 ) low concentrating ability may persist for some time after all other signs of renal disease have disappeared. Sometimes an exacerbation adds further unwelcome proof that healing is not yet final (Case 11).

When, however, not only the clearance, but also the concentration test show consistently normal values, there appears to remain little danger that recovery will not continue to completion. For this reason the concentration test is a desirable adjunct to the clearance in following the course of acute nephritis, particularly when the clearance approaches normal values.

On the other hand, as shown by Cases 4 and 5, the concentration test is much less sensitive than the clearance in indicating the beginning of recovery and its progress to approximate subjective and clinical completion. 


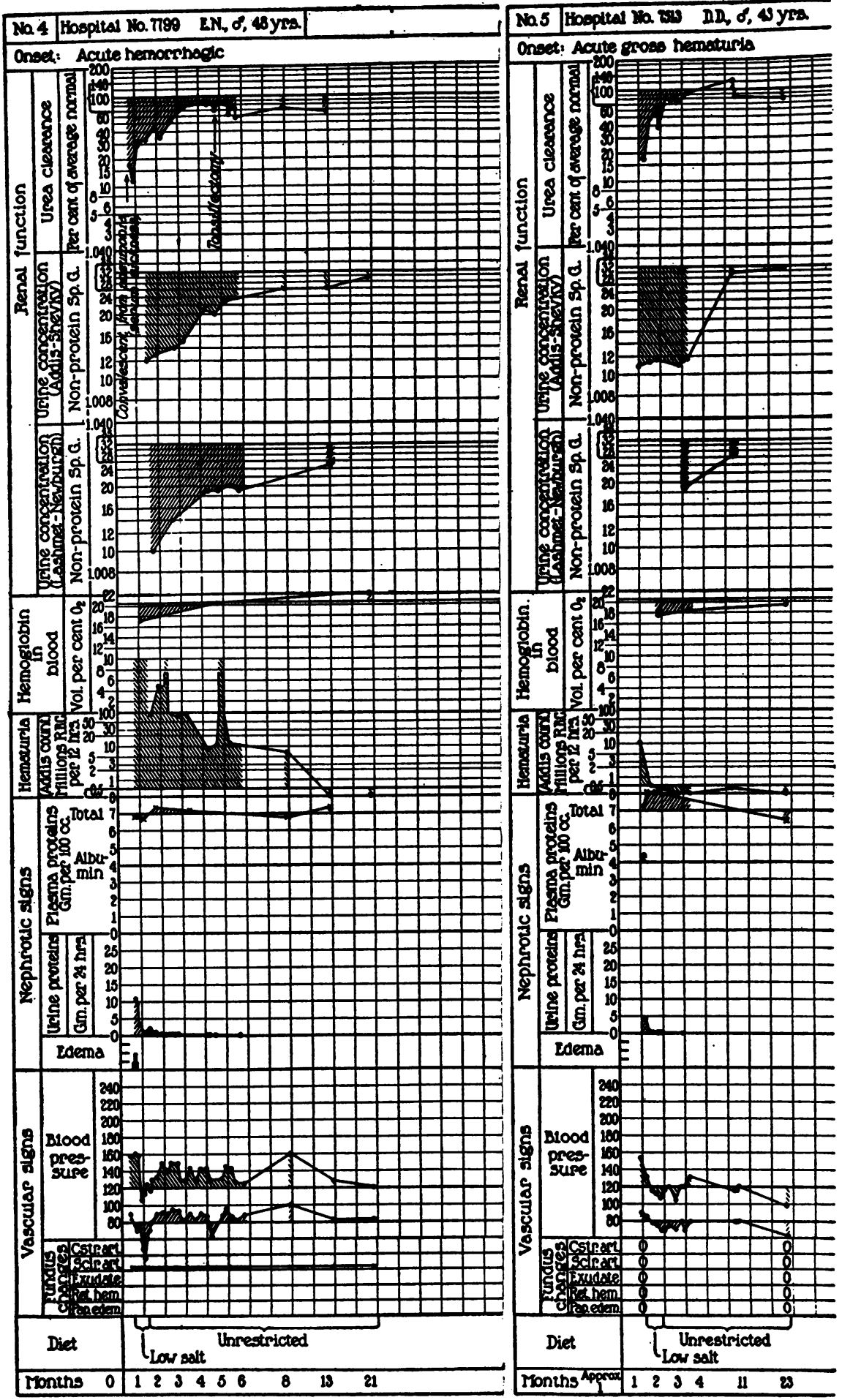

Fig. 7. Course of Two Cases Recovering from Acute Nephritis

In each the urea clearance (top curve) rises to normal two or more months before the specific gravity in either concentration test (next 2 curves below) attains normal height. The first figure immediately after "Months" at the bottom indicates the time between apparent onset of nephritis and admission to hospital. 

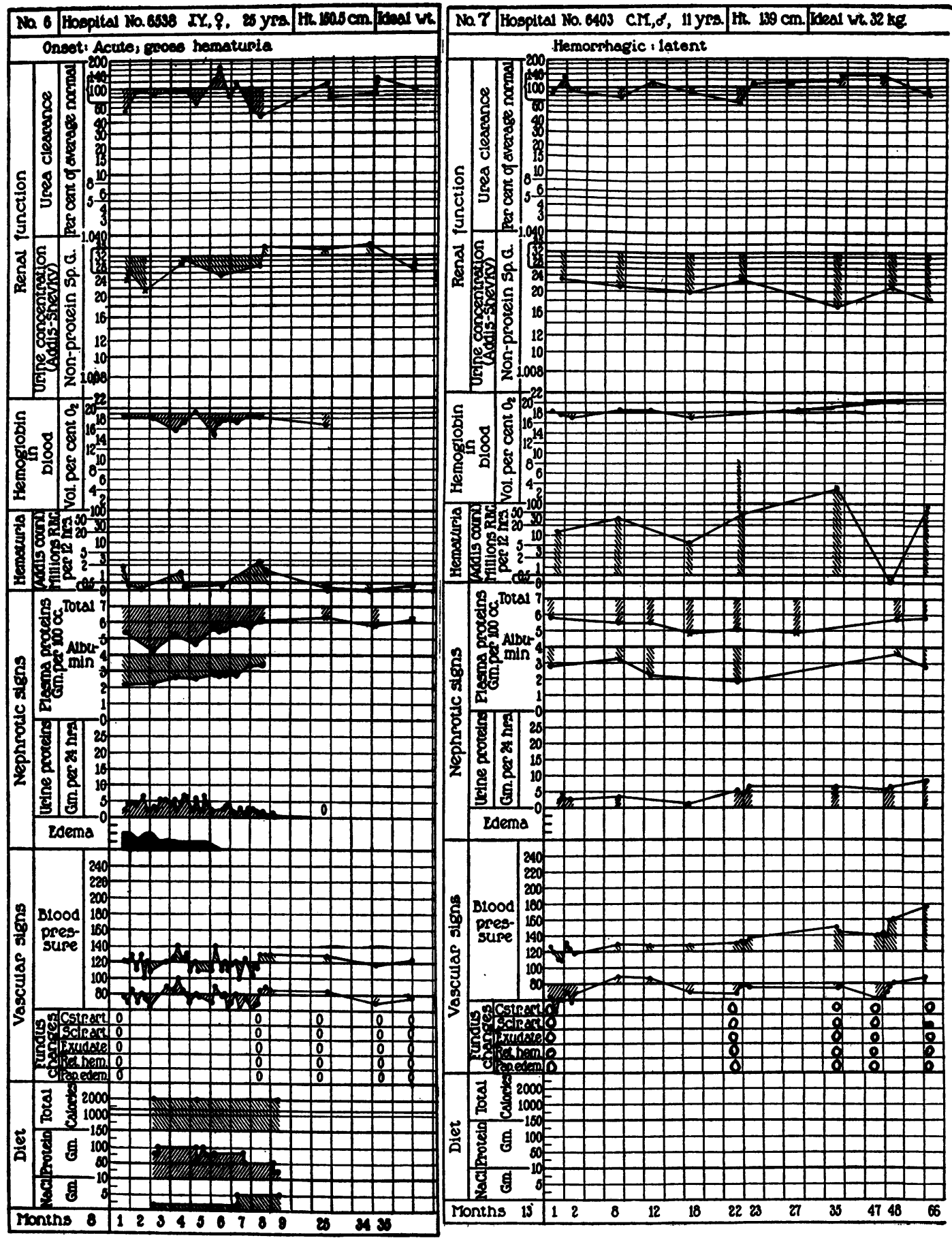

Fig. 8. Urea Clearance and Addis-Shevky Specific Gravities During Latent Stage of HEMORRHAGIC NePhritis

Case 6, who eventually recovered, showed parallelism between urea clearance and AddisShevky concentration test. Case 7 has had normal urea clearance and low Addis-Shevky concentration test for 5 years. Continued hematuria, proteinuria, and subnormal plasma protein content confirmed the concentration test in indicating that some renal lesion persists. 


\section{Latent stage of hemorrhagic nephritis}

In this stage, where recovery from initial nephritis has paused with the attainment of subjective well being, but with persistence of some signs, such as proteinuria, slight hematuria, or hypertension, the urea clearance usually returns to normal. The concentration test may also become normal, or it may continue to give low results. In Case 6, Figure 8, a patient who eventually recovered, parallelism between the two tests is seen, while in Case 7 a low concentration test has persisted for nearly five years, despite a consistently normal clearance. In this patient the persistence of hematuria and proteinuria indicates that the kidneys have not returned to normal.

\section{The chronic active stage of hemorrhagic nephritis}

It is in this stage (defined by Van Slyke, Stillman, et al. (1930) as that in which the disease has assumed a chronic character, but with the urea clearance still above 20 per cent of normal) that one is most likely to find parallelism between the urea clearance and the concentration test. A large proportion of the data presented in Figures 1 to 5 are from cases in this stage. The average specific gravities corresponding to given clearances are indicated by the locus of the broken line bisecting the fan-shaped area, included between the two lines bounding the field of the main body of results, in each of these figures. The wide range of variation from the average is indicated by the range of clearances lying within the field at the level of any given clearance. The degree of correlation in this stage is also illustrated by Cases 8 and 9, during the periods when their urea clearances were definitely above 20 per cent of normal (Figs. 9 and 10).

\section{Advanced cases with fixation of urine specific gravity, while the urea clearance continues to show important variations in function}

The fall from 20 or 30 per cent to 5 per cent of mean normal urea clearance has been found to correspond to a change from a clinical condition still compatible with occupational activity to one which ushers in uremia (Van Slyke, Stillman, et al. (1930)). The concentration tests, however, appear in this range to be relatively insensitive to variation. Thus in Figure 1 the cases with urea clearance between 5 and 20 per cent of mean normal show by the Lashmet-Newburgh test, specific gravities between 1.0075 and 1.012 scattered indiscriminately without apparent relationship to the urea clearance. A similar behavior of results of the other concentration tests is shown by Figures $2,3-\mathrm{A}, 4-\mathrm{A}$, and 5-A. The course of Case 9, Figure 10, beginning with the 17th month, of Case 10, Figure 11, throughout the period charted, and of Case 11, Figure 11, after the 6th month, illustrate the behavior of the two tests during the progress of advanced nephritis. The gradual fall of the urea clearances contrasts 


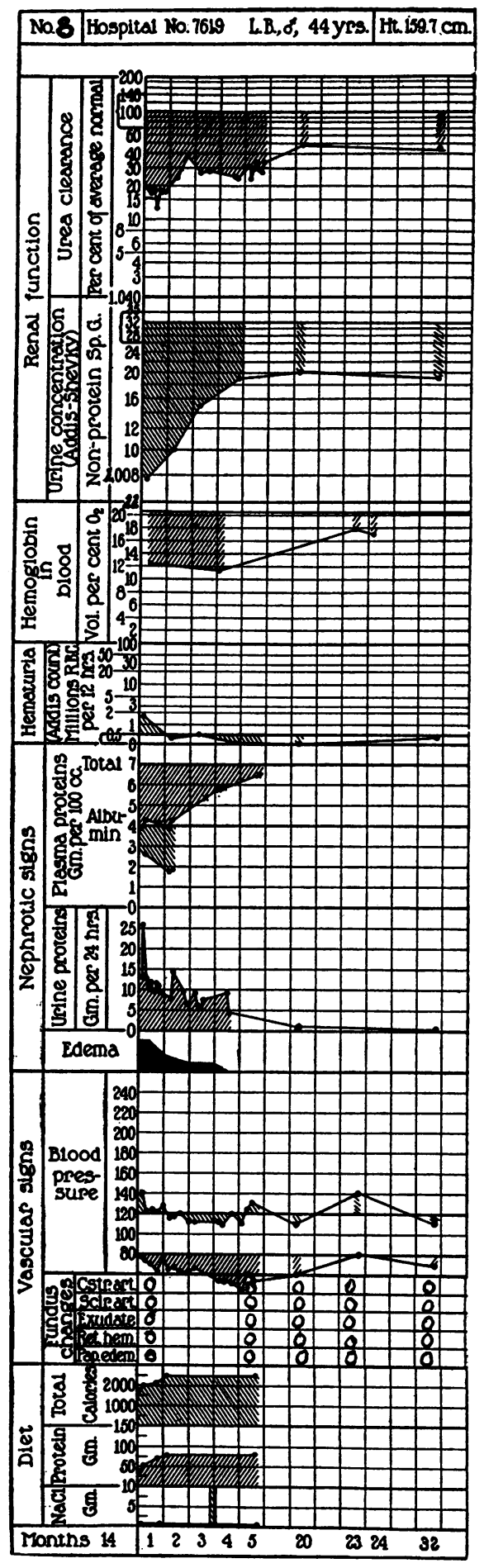

Fig. 9. Case of Chronic Active Hemorrhagic Nephritis, Showing Degree of Correlation Between Clearance and Concentration Tests During Progress of the Disease. 


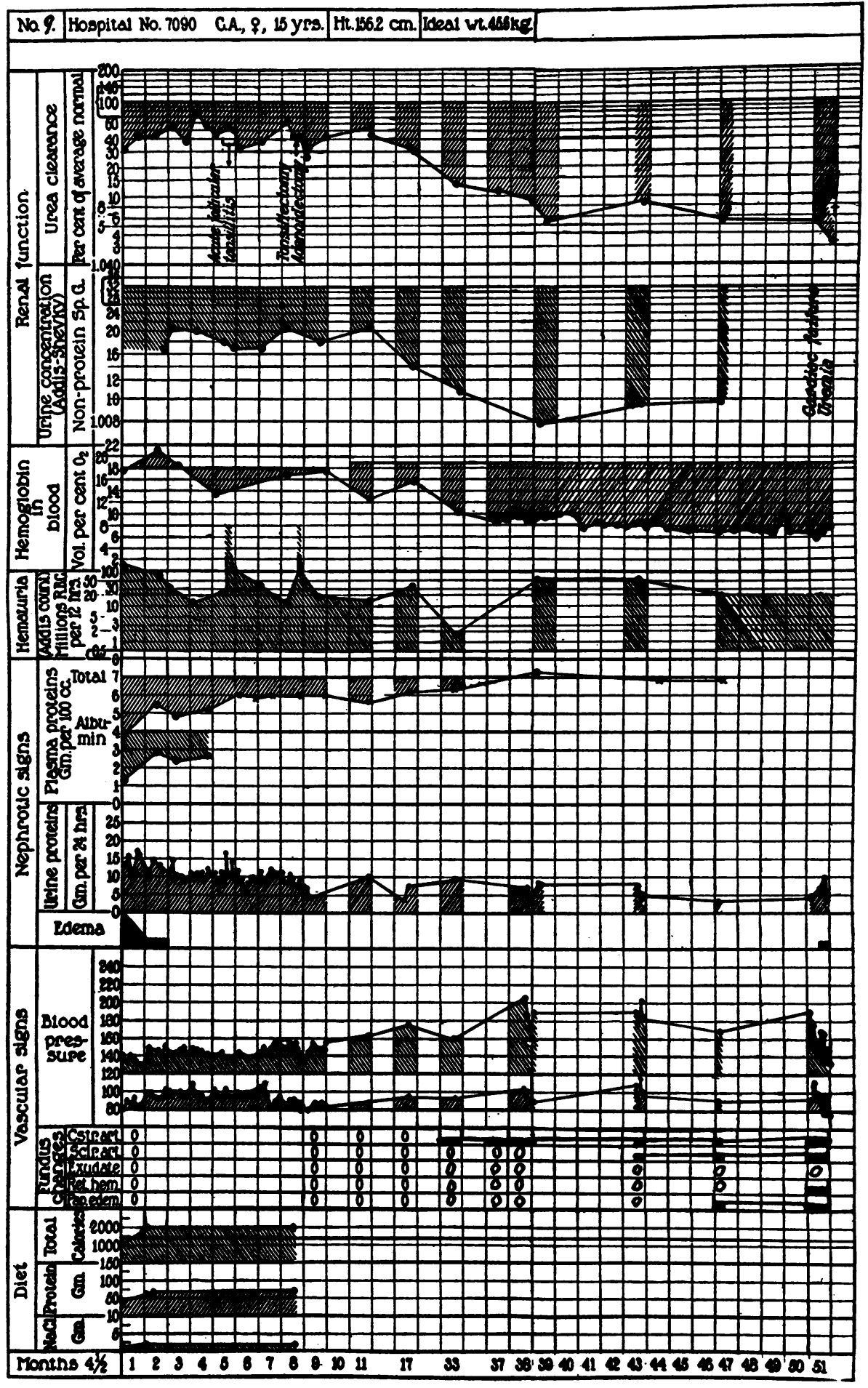

Fig. 10. Case of Chronic Active Hemorrhagic Nephritis, Showing Degree of Correlation Between Clearance and Concentration Tests During Progress of the Disease. 


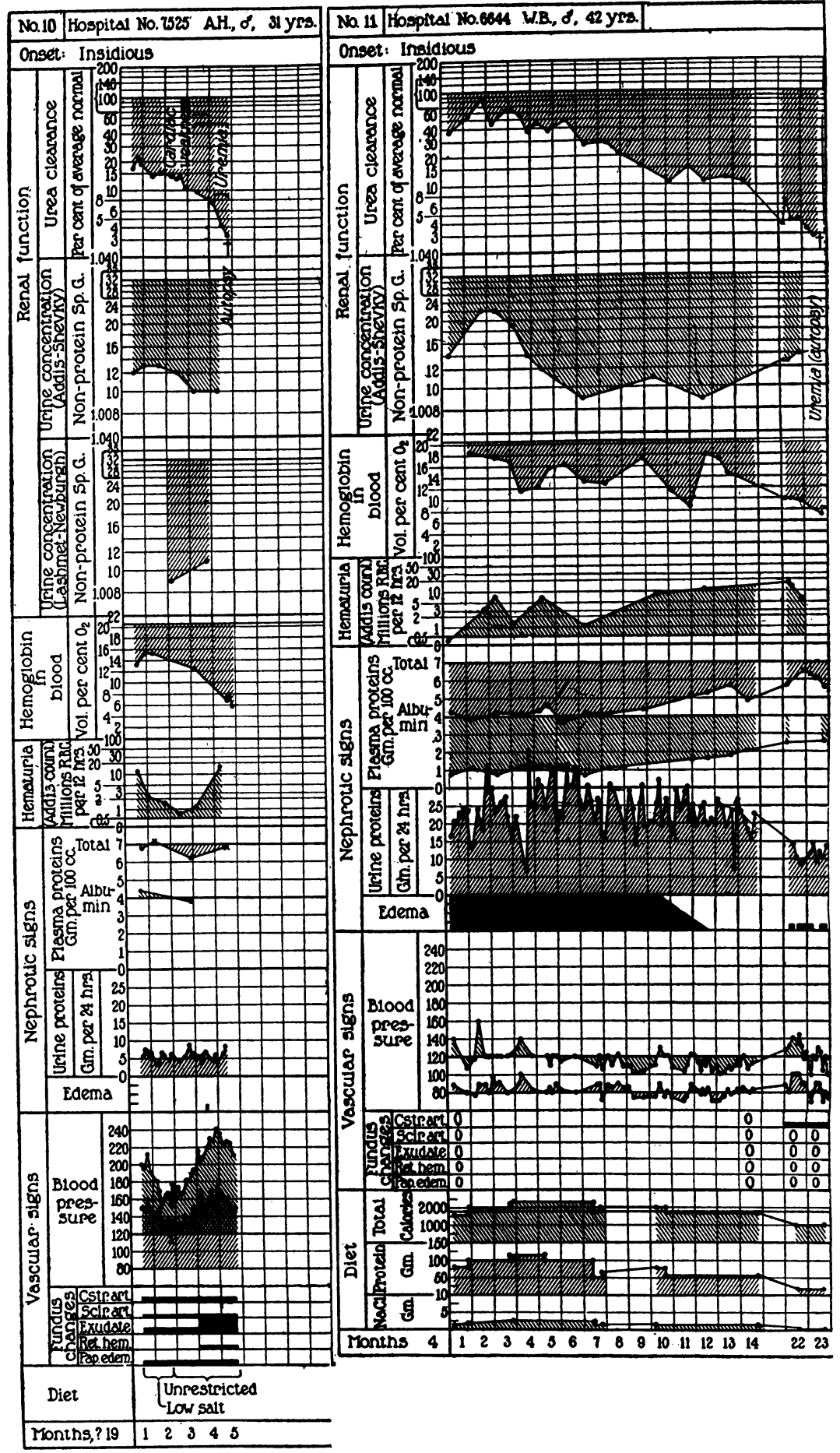

Fig. 11. Urea Clearance and Addis-Shevky Specific Gravity During Progress of Advanced Nephritis in Two Cases 
with the stationary condition of urine specific gravities which, having already reached the zone of minimum values, show no further significant changes.

While the urea clearance therefore continues to be of value in showing the progress of the disease and the margin of remaining renal function in advanced chronic nephritis, the concentration test does not.

\section{Essential hypertension and nephrosclerosis}

Cases of arteriosclerosis with normal function by the urea clearance are likely to show also normal function by concentration tests (Case 12, Figure 12).

As renal function fails, the clearance and concentration tests show the same relative behavior as in chronic hemorrhagic nephritis. There is some degree of parallelism until the clearance has fallen to 20 to 30 per cent of normal. By that time, however, the gravity has approached its minimal value, and can not be of much assistance in following the further course of the disease (Case 14, Figure 12).

\section{Nephrosis}

In nephrosis with slight or moderate diminution of urea clearance the concentration test may parallel the clearance (Cases 15 and 16, Figure 13). Whether nephrotic cases, like hemorrhagic cases, show exceptions to this parallelism we can not state, as the number of nephrotic cases observed has been too small.

\section{Conditions invalidating the concentration test}

That various physiological and pathological conditions of extrarenal origin can at times invalidate the results of concentration tests has been well recognized by the authors of these tests. Addis and Shevky (1922) pointed out that extrarenal influences of endocrine, nervous, or metabolic origin could increase the water output, or decrease the solid output, during the period of their test, and produce lowering of specific gravity simulating that caused by renal deficit. Among the metabolic factors they mentioned unusually low nitrogen or salt content of the diet. Usually, however, according to the present authors' experience, the normal subject automatically adjusts his water intake so that these factors appear only rarely to invalidate the results.

Specific disturbing factors pointed out by Volhard (1918) are unusual desiccation or water flooding of the subject during the days preceding the test, storage or excretion of edema fluid in subjects of the nephrotic type during the test, and cardiac decompensation.

Mosenthal (1930) states: "A low fixed specific gravity ... . is found in many widely varying conditions ; marked anemia, elimination of edema, 


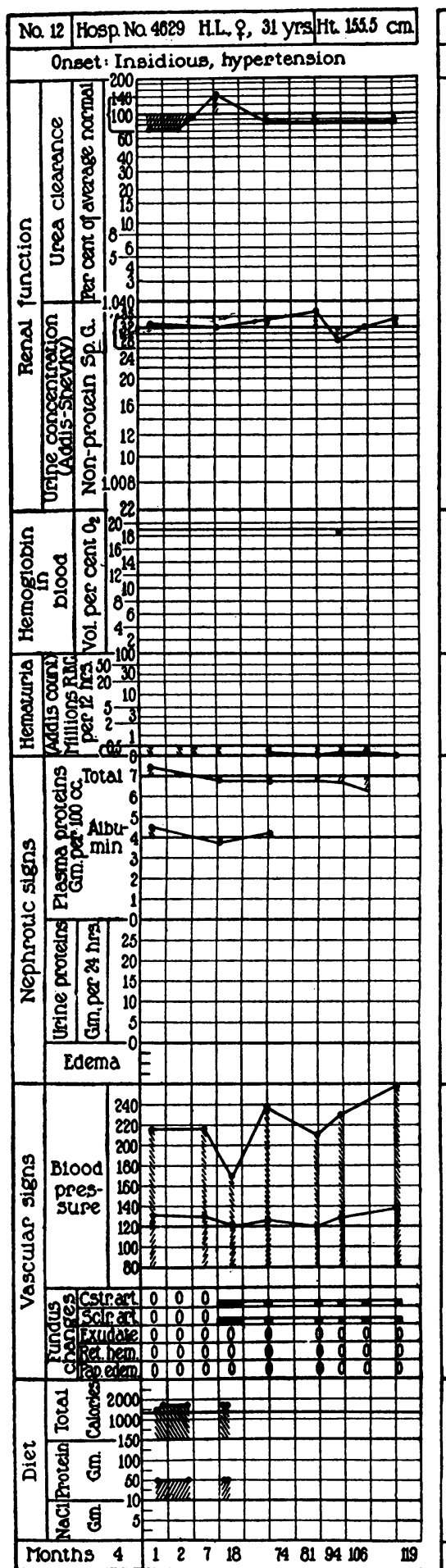

\begin{tabular}{|l|l|}
\hline No. 13 & Hosp. Na 8855 BA, . . 20 yrs \\
\hline
\end{tabular}
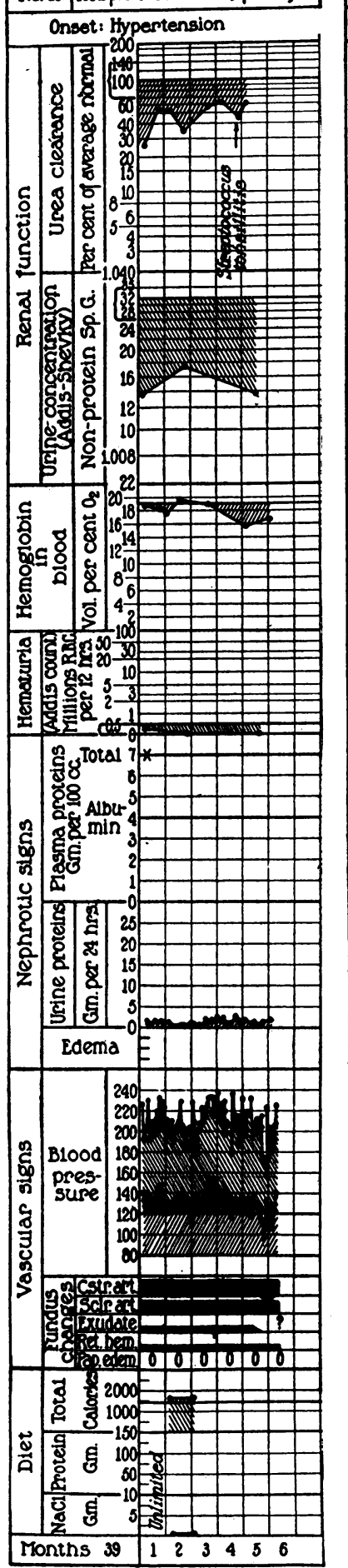

No. 14 Hospital No. 7963 J.D., ó, 24 yss.

Onset : Insidious, hypertension
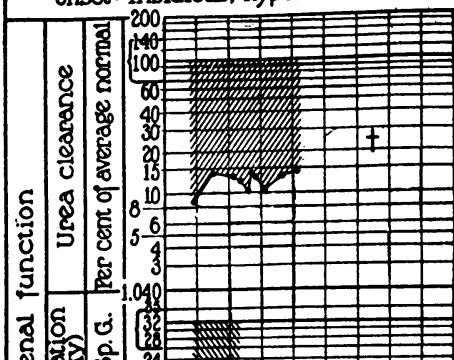

的$$
\text { 窟 }
$$

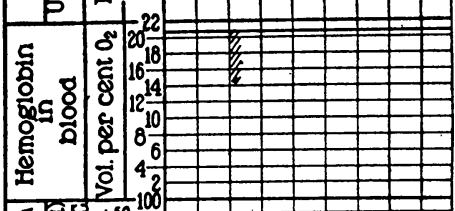

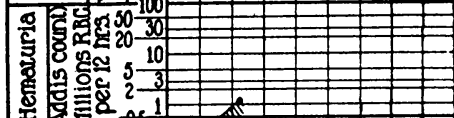

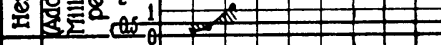
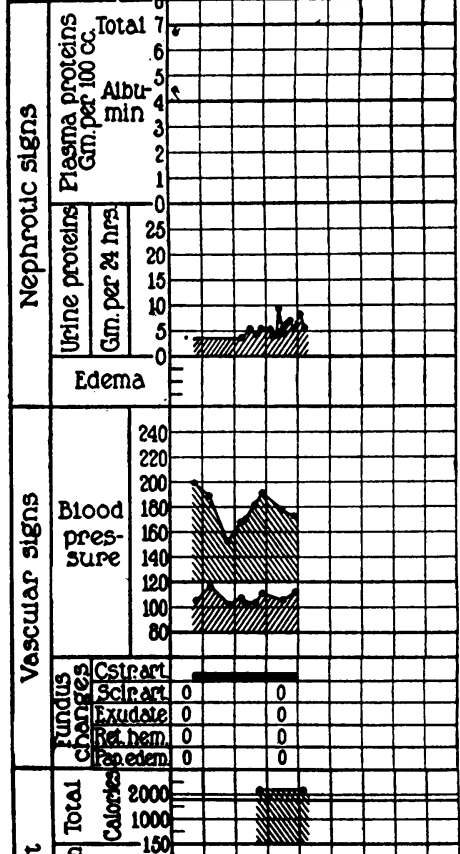
คे

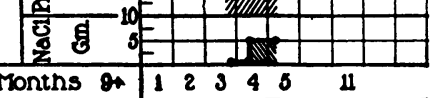

Fig. 12. Urea Clearance and Addis-Shevky Specific Gravity in Three Cases Beginning as Essential Hypertension

In Cases 13 and 14 proteinuria has developed, and the function tests indicate renal destruction. moderate in Case 13, advanced in Case 14. 


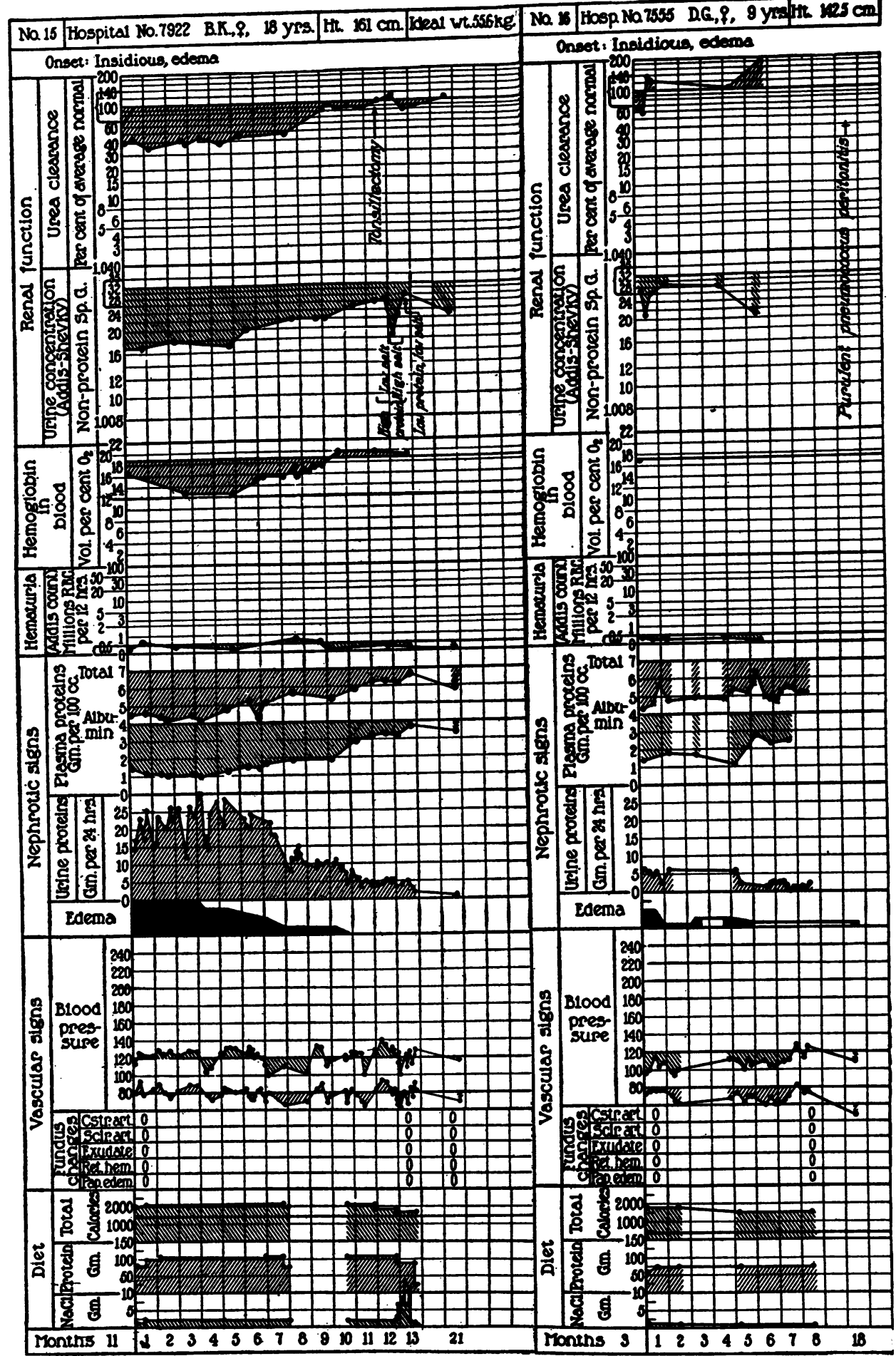

Fig. 13. Two Cases of Nephrosis Showing the Degree of Correlation Between the Clearance and Concentration Test

The urine specific gravities of Case 15 during the 13th month show the unexpected influence of increased salt intake in lowering the specific gravity obtained in the concentration test (see text, p. 990). 
pyelitis, polycystic kidney, prostatic hypertrophy, urethral stricture, paralysis of the bladder (as in tabes dorsalis or tumor of the cord), and others. A lower fixed specific gravity occurs in diabetes insipidus."

Observations made on Case 15 (Figure 13) during the 13th month after admission illustrate the unpredictable influence which extrarenal factors may have on the results of a concentration test. This patient, nearing recovery from degenerative Bright's disease, could concentrate to 1.027 when on her usual diet, which was fairly high in protein, but contained only 1 to 2 grams of salt per day. Addis and Shevky (1922) reported that in normal subjects low protein or low salt intake sometimes caused subnormal specific gravities in the concentration test. We consequently expected that raising the salt intake might increase the specific gravity from a minimal normal to the usual full normal value (1.030 to 1.034). On the contrary, when the salt intake was raised to 10 to 12 grams on two occasions the specific gravity fell to 1.018 and 1.023 respectively. Apparently the diuretic effect of the salt caused the excretion of relatively more water than solids.

Despite the possible interference of such invalidating factors, however, it is our experience that, when signs of renal lesion exist or have existed, consistently low results in concentration tests afford presumptive evidence that some of the renal damage persists, even though the urea clearance is normal.

\section{The relative influence of different urinary constituents on the specific gravities obtained in the concentration tests}

Figure 14 indicates a close correlation between the mineral salt content and the specific gravity of urine voided under the conditions of the Lashmet-Newburgh concentration test. That the mineral salts are chiefly responsible for the extent by which the urine gravity exceeds that of water appears from the following considerations.

From Figure 14 it is evident that with increase in specific gravity the total base concentration, in milli-equivalents, usually increases at about the same rate as the millimolar urea concentration of the urea, and that a urine of specific gravity 1.030 , obtained under the conditions of the test, has an average mineral content of about 400 milli-equivalents per liter and a urea content of about 400 millimols. The specific gravities in Table I (corrected to apply to water at the same temperature as unity) are taken from Landolt-Börnstein's " Tabellen.”

It is obvious from Table I that 1 milli-equivalent of base combined with the anions present in urine raises the specific gravity from 2 to 5 times as much as 1 millimol of urea. One gram equivalent of base combined with $\mathrm{Cl}$ or acetate anion has about 2 times the effect of one gram molecule of urea, base with lactate, $\mathrm{SO}_{4}$ or $\mathrm{HPO}_{4}$ has about 3 times, and 
TABLE I

Specific gravities at $20^{\circ} \mathrm{C}$. corrected to water at same temperature (Landolt-Börnstein)

\begin{tabular}{|c|c|c|}
\hline Solute & Concentration & $\begin{array}{l}\text { Specific } \\
\text { gravity }\end{array}$ \\
\hline 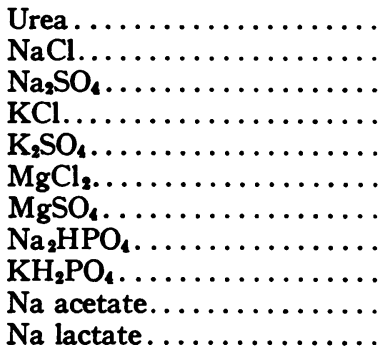 & $\begin{array}{l}0.4 \text { molar } \\
0.4 \text { milli-equivalent } \\
0.4 \text { milli-equivalent } \\
0.4 \text { milli-equivalent } \\
0.4 \text { milli-equivalent } \\
0.4 \text { milli-equivalent } \\
0.4 \text { milli-equivalent } \\
0.4 \text { milli-equivalent } \\
0.4 \text { milli-equivalent } \\
0.4 \text { milli-equivalent } \\
0.4 \text { milli-equivalent }\end{array}$ & $\begin{array}{l}1.007 \\
1.016 \\
1.025 \\
1.018 \\
1.027 \\
1.015 \\
1.024 \\
1.026 \\
1.038 \\
1.015 \\
1.021\end{array}$ \\
\hline
\end{tabular}

base with $\mathrm{H}_{2} \mathrm{PO}_{4}$ about 5 times the effect of one mol of urea. Figure 14 indicates that in urine excreted under the conditions of the LashmetNewburgh test, about $1 / 3$ of the base is present as chlorides, which in $0.4 \mathrm{~N}$ concentration raise the specific gravity by 0.016 or 0.017 units. The other $2 / 3$ must be in great part in the group of salts which in $0.4 \mathrm{~N}$ concentration cause specific gravity increases of 0.025 or more units. If we assume that, in the urine of specific gravity 1.030 , the total base is 0.4 normal, and $1 / 3$ of the salts are present as chlorides, $2 / 3$ as sulfates and phosphates, the specific gravity due to the minerals would be about 1.023. Adding 0.007 due to the urea gives the entire gravity value 1.030 . The calculation is, of course, only a rough approximation, but it serves to show that in urines collected under the conditions of this test, about $3 / 4$ of the rise in specific gravity above that of water may ordinarily be attributed to the mineral salts, and about $1 / 4$ to urea, with other organic solids of relatively slight influence.

In cases with normal urea clearance and low urine gravities, the latter are attributable to the fact that the patients excrete urine containing a low concentration of nonprotein solids, of which the most important with regard to effect on specific gravity are the mineral salts. In the LashmetNewburgh tests the low gravities appear not due to high volumes, for the urine volumes in these cases have not been high (hollow circles to left of specific gravity 1.026 line in Figure 15). The low gravities must therefore be attributed to a low total excretion of salts, in the 2-hour period. In the cases with normal clearance and low Addis-Shevky concentration tests, however (Figure 16), the 12-hour night urines, although sometimes normal in volume, were often of large volume. The low gravities in some of these cases therefore appear attributable to nocturnal polyuria, in others to a low output of salts. 


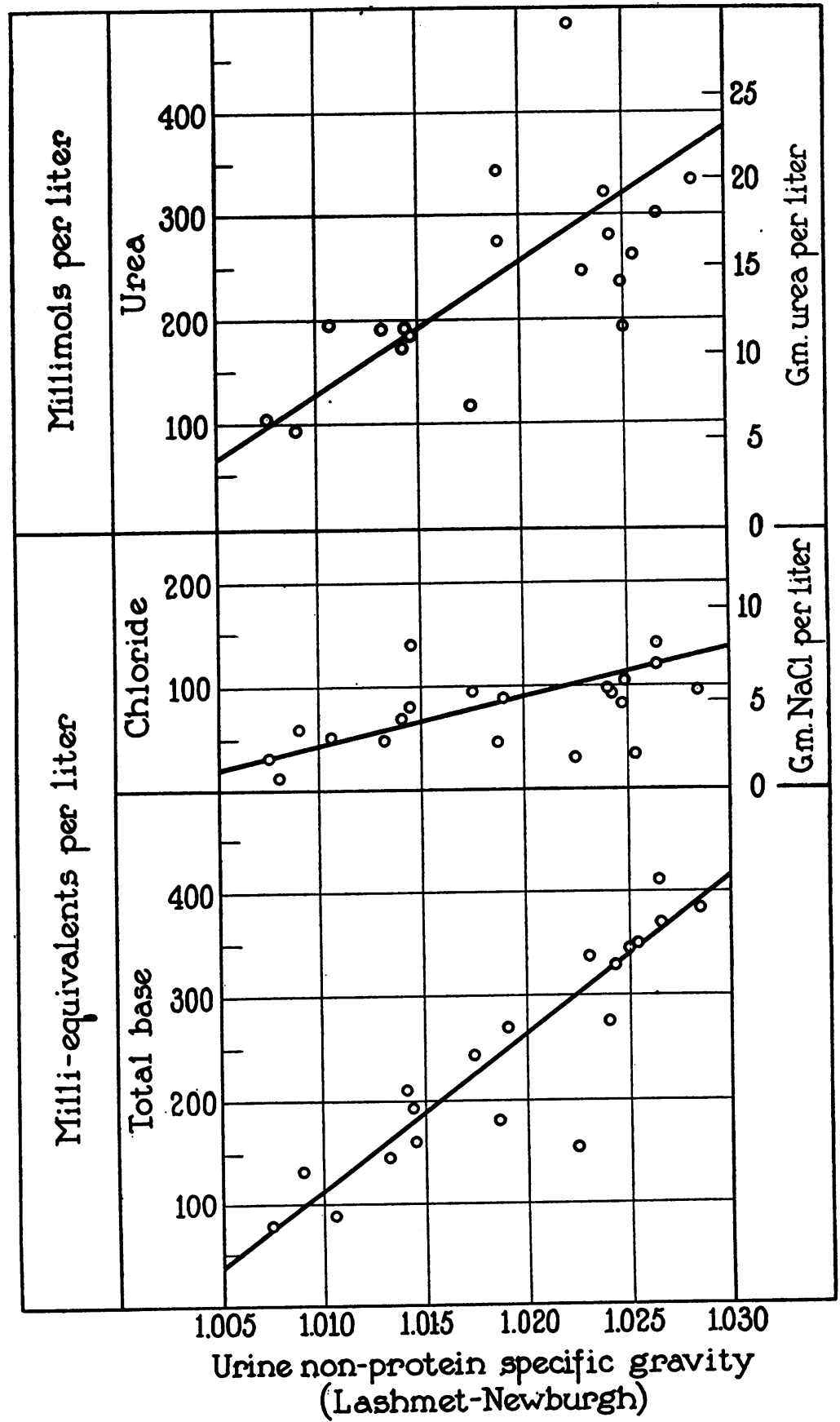

Fig. 14. Relationship of Urine Specific Gravity to Urea, Chloride, and Total Base Concentrations 


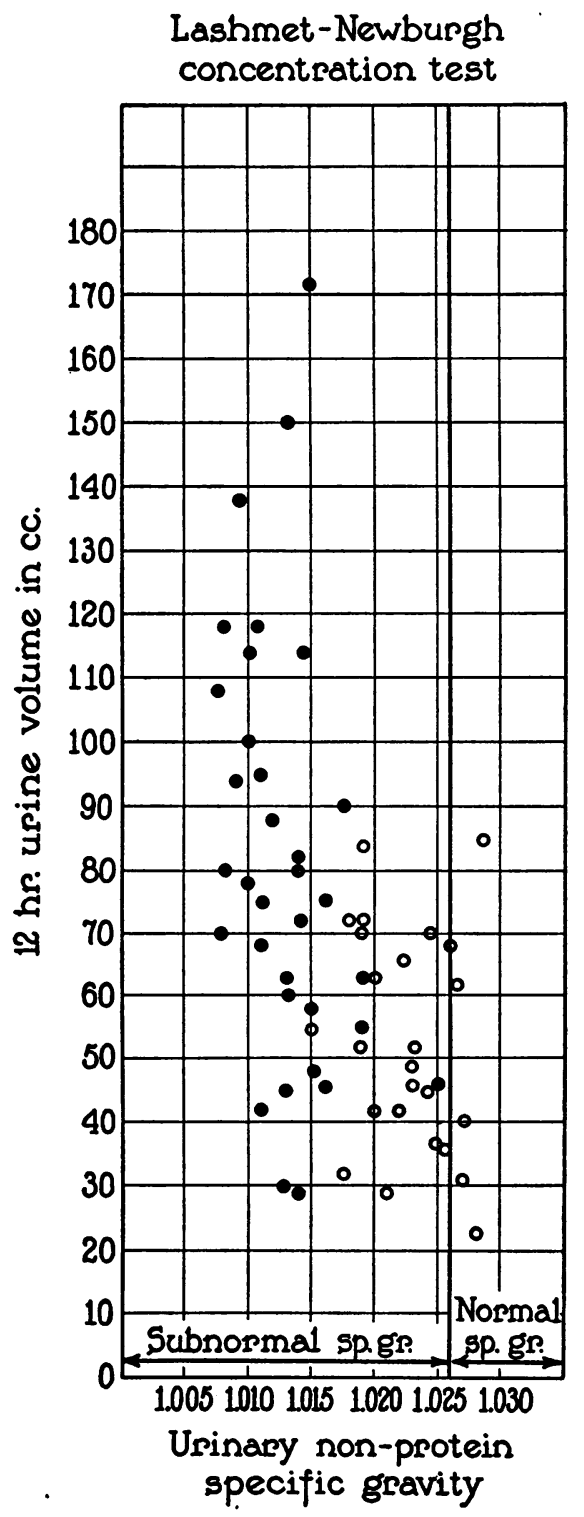

- Blood urea clearance

$0=$. "

Fig. 15

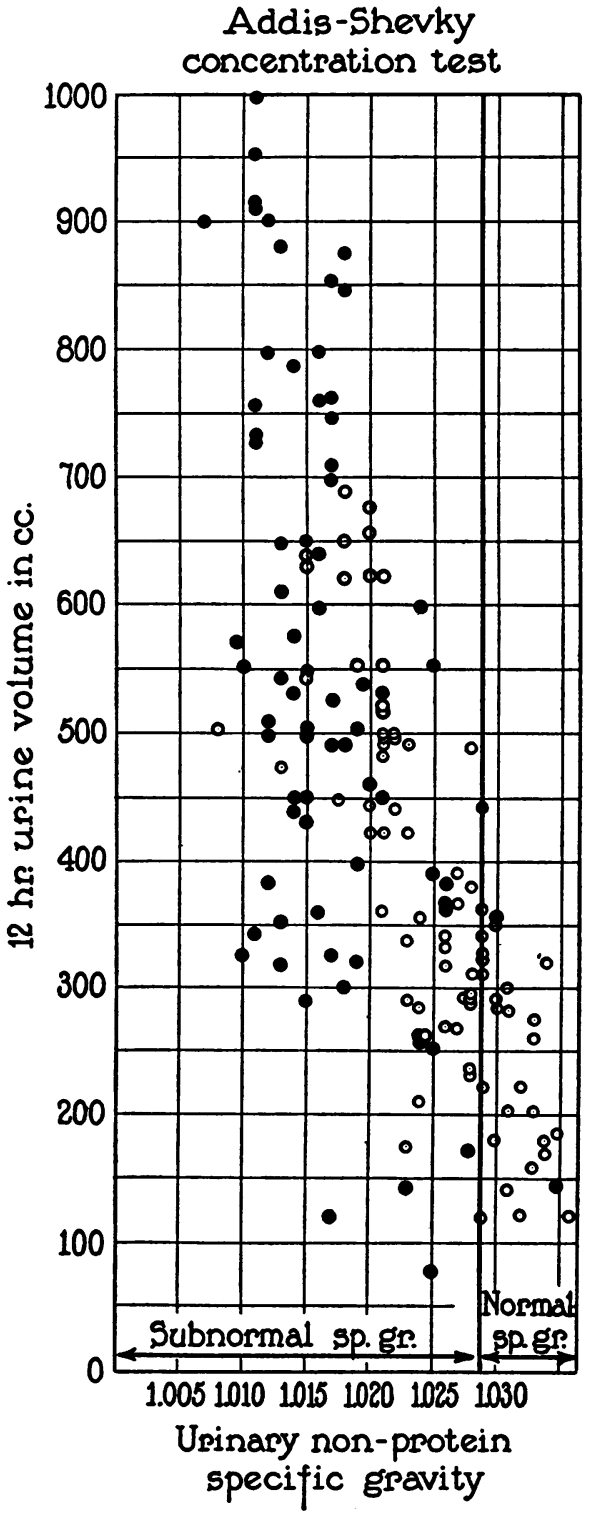

below $75 \%$ of mean normal. $75 \%$ of mean normal op above.

Fig. 16

Fig. 15. Urine Volumes in Lashmet-Newburgh Test Compared with Specific Gravities; in Cases Indicated by ๑, with Urea Clearances Below the Normal Range, and in Cases, Indicated by O, with Normal of Hypernormal Urea Clearances.

Fig. 16. Urine Volumes in Addis Test Compared with Specific Gravities; in Cases Indicated by $\bullet$, with Urea Clearances Below the Normal Range, and in Cases, Indicated by O, Within or Above the Usual Normal RANGES. 


\section{Dilution tests}

Comparison of the urea clearance with results of the two modifications of Volhard's dilution test after water ingestion are shown with regard to minimal urine specific gravities in the lower parts of Figures 3-A and $4-\mathrm{A}$, and with regard to urine volumes in Figures $3-\mathrm{C}, 4-\mathrm{C}$, and $5-\mathrm{C}$. In general the significance is similar to that of the concentration tests, except that the results of dilution tests appear to be less sensitive. The dilution tests of Figures 3 and 4 both yielded frequent normal specific gravities (under 1.003 or 1.005 ) until the urea clearance was below 30 per cent of normal, and sometimes when it was still lower. The maximal half-hour urine volume (Figure 4-C) showed similar results. The total 4-hour volume (Figure $3-C$ ) was always below normal in cases with less than 40 per cent of average normal clearance. Of the different data obtained by the dilution test, the 4-hour volume appears to have a somewhat more consistent relation to the urea clearance than does the maximal half-hourly volume or minimal specific gravity. In general, however, all the dilution tests yielded less consistent results than the concentration tests.

\section{Difference between concentration and dilution}

The difference between the maximum urine specific gravity obtained in a concentration test and the minimum obtained in a dilution test on the same subject serves as an indication of the elasticity of renal function, which is high in the normal kidney, and decreases in advanced renal disease. Figures 3-B and 4-B compare the value of this difference with the clearance. In Figure 5-B a similar comparison of the spontaneous variation of the gravity with the clearance is shown.

In all cases with less than minimum normal urea clearances (= less than 70 per cent of average normal) the maximum-minimum specific gravity difference by the Lundsgaard test (Figure 3-B) was less than normal limit of 0.020 . With the Rosenberg test, however (Figure 4-B), the maximumminimum gravity difference frequently remained normal until the clearance dropped below 35 per cent, and the Mosenthal test (Figure 5-B) appears similar.

As a quantitative measure of the degree of functional loss, the gravity difference appears to have little accuracy: the same gravity difference may be found with a urea clearance of 60 per cent of normal as with a clearance 10 per cent.

\section{CONCLUSIONS}

1. Concentration tests, done after adequate preliminary regime, and with correction for the effect of protein on the specific gravity, are sensitive for qualitative detection of damaged renal function. The Mosenthal test, in which the maximum urine gravity is noted during the spontaneous variations of the day, without preliminary regime, yields similar, although perhaps less sensitive, results. 
2. For measuring the extent of renal damage, however, concentration tests do not appear to be suited. Although the extent of fall in urine concentration shows statistical correlation to the urea clearance and severity of renal disease, the disagreements in given cases may be extreme. A patient who has practically recovered from acute nephritis and regained a normal urea clearance, may by concentration tests continue for some time to yield urine of 1.009 to 1.012 specific gravity, the same as a patient in terminal uremia with 3 to 5 per cent of normal clearance. In chronic cases sufficiently advanced to show urea clearances 20 to 30 per cent of normal, concentration tests may already show minimal urine gravities, and will then reveal no further changes during subsequent progress of the disease, while the clearance continues to fall until it reaches the uremic level of 3 to 5 per cent. The extent of urine specific gravity fall shows no such uniform relationship to the severity of renal disease as does the extent of urea clearance fall.

3. Nevertheless, in observation of nephritis, a concentration test may well be used to supplement the urea clearance for the following purposes. (1) When a concentration test yields urine of more than 1.026 specific gravity, one may assume as a rule that the renal function is normal, and the clearance test may be omitted. (2) In recovering acute cases, persistent low gravities may continue to show evidence of residual renal abnormality for weeks or months after the urea clearance has returned to normal. In assisting to decide when recovery is complete the concentration test is therefore significant.

4. Correlation of urine composition with specific gravity in the concentration tests indicates that the chief factor in determining the specific gravity is the concentration of mineral salts. Whereas the urea clearance measures the ability of the kidneys to excrete urea, the concentration test appears to measure chiefly their ability to concentrate mineral salts.

5. The dilution tests which were studied yielded, with nephritic patients, less consistent results than the concentration tests; hence there seems to be no object in adding routinely a test of dilution to one of concentration.

6. The difference between maximum and minimum specific gravity in the combined concentration and dilution tests, although more sensitive than the dilution test alone, does not appear in our observations to be more significant than the maximum specific gravity alone.

Note on urine specific gravity determinations. The modified Westphal balance shown in Figure 17 was adopted for use in concentration tests after most of the data presented in the above paper had beeen collected. It has, however, proven to be especially advantageous for routine tests, because it affords results exact to 0.0005 , and requires no more time than the reading of an ordinary urinometer, which is not easy to make with an error less than 0.0020 . To the beam of an ordinary Westphal balance is 
attached the metal scale divided into 50 divisions between the knife-edge fulcrum and the point of suspension of the beam. The solid glass plummet is of $10 \mathrm{cc}$. volume, so that a change of 0.001 in specific gravity of the liquid tested changes the load by $10 \mathrm{mgm}$. A $500 \mathrm{mgm}$. rider is used on the beam, so that each division represents a specific gravity change of 0.001 . The balance is sensitive to a shift of half a division by the rider. The balance is adjusted to indicate 1.000 specific gravity when the fluid is water at the chosen standard temperature, $20^{\circ}$ in the case of our work. ${ }^{8}$

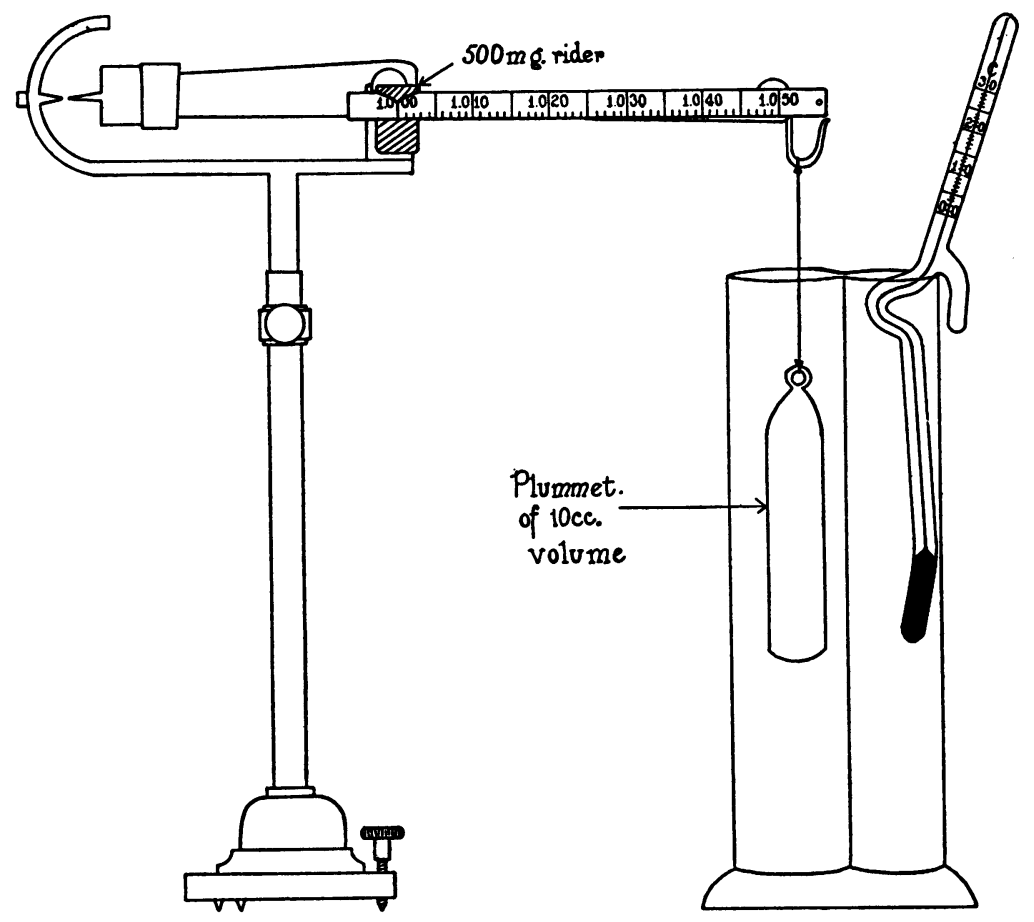

Fig. 17. Westphal Specific Gravity Balance Modified for Routine Use WITH URINE

\section{BIBLIOGRAPHY}

Addis, T., A clinical classification of Bright's disease. J. A. M. A., 1925, 85, 163.

Addis, T., and Shevky, M. C., A test of the capacity of the kidney to produce urine of high specific gravity. Arch. Int. Med., 1922, 30, 559.

Bruger, M., and Mosenthal, H. O., Urea clearance test as an index of renal function. IV. The urea clearance test in relation to other tests and measures of renal function. Arch. Int. Med., 1932, 50, 556.

6 The balance was made for us from an ordinary Westphal balance by Eimer and Amend, of New York. 
Hedinger, M., and Schlayer, Utber die Prüfung der Nierentätigkeit durch Probemahlzeit. Deutsches Arch. f. klin. Med., 1914, 114, 120.

Korányi, A. von, Beiträge zur Theorie und zur Therapie der Niereninsufficienz, unter besonderer Berücksichtigung der Wirkung des Curare bei derselben. Berl. klin. Wchnschr., 1899, 36, 781.

Kövesi, G., and Roth-Schulz, W., Ueber Störungen der wassersecernirenden Thätigkeit diffus erkrankter Nieren. Berl. klin. Wchnschr., 1900, 37, 321.

Lashmet, F. H., and Newburgh, L. H., The specific gravity of the urine as a test of kidney function. J. A. M. A., 1930, 94, 1883.

Lashmet, F., and Newburgh, L. H., An improved concentration test of renal function. J. A. M. A., 1932, 99, 1396.

Lundsgaard, C., Modification of the concentration-dilution test. 1920. (Unpublished.)

McIntosh, J. F., Möller, E., and Van Slyke, D. D., Studies of urea excretion. III. The influence of body size on urea output. J. Clin. Invest., 1928, 6, 467.

Möller, E., McIntosh, J. F., and Van Slyke, D. D., Studies of urea excretion. II. Relationship between urine volume and the rate of urea excretion by normal adults. J. Clin. Invest., 1928, 6, 427.

Moore, N. S., and Van Slyke, D. D., The relationships between plasma specific gravity, plasma protein content and edema in nephritis. J. Clin. Invest., 1930, 8, 337.

Mosenthal, H. O., Renal function as measured by the elimination of fluids, salt and nitrogen, and the specific gravity of the urine. Arch. Int. Med., $1915,16,733$.

Mosenthal, H. O., Renal function as measured by the elimination of fluids, salt, nitrogen and the specific gravity of the urine. II. The effect of high, low, and normal diets. Arch. Int. Med., 1918, 22, 770.

Mosenthal, H. O., Variations in blood pressure and nephritis. Oxford Monographs on Diagnosis and Treatment. Vol. 7. Edited by H. O. Christian, New York, Oxford University Press, 1930.

Ong, H. L., Verglijkend Onderzoek over verschillende Nierfunctieproeven. N. V. v/h Van Creveld and Co., Amsterdam, 1932, p. 266.

Peters, J. P., and Van Slyke, D. D., Quantitative Clinical Chemistry. Vol. I. Interpretations. Williams and Wilkins Co., Baltimore, 1931.

Peters, J. P., and Van Slyke, D. D., Quantitative Clinical Chemistry. Vol. II. Methods. Williams and Wilkins Co., Baltimore, 1932.

Pratt, J. H., The dilution and concentration tests of renal function. Boston M. and S. J., 1926, 195, 203.

Rosenberg, M., Die Klinik der Nierenkrankheiten. Berlin, 1927, p.44. Quoted by Volhard and Becher.

Shevky, M. C., and Stafford, D. D., A clinical method for the estimation of protein in urine and other body fluids. Arch. Int. Med., 1923, 32, 222.

Van Slyke, D. D., Determination of urea by gasometric measurement of the carbon dioxide formed by the action of urease. J. Biol. Chem., 1927, 73, 695.

Van Slyke, D. D., Hiller, A., and Berthelsen, K., A gasometric micromethod for determination of iodates and sulfates, and its application to the estimation of total base in blood serum. J. Biol. Chem., 1927, 74, 659. 
Van Slyke, D. D., Stillman, E., Möller, E., Ehrich, W., McIntosh, J. F., Leiter, L., MacKay, E. M., Hannon, R. R., Moore, N. S., and Hohnston, C., Observations on the different types of Bright's disease, and on the resultant changes in renal anatomy. Medicine, 1930, 9, 509.

Volhard, F., Die doppelseitigen hämatogenen Nierenkrankungen. Verlag von Julius Springer, Berlin, 1918, p. 60.

Volhard, F., and Becher, I., Die Klinischen Methoden der Nierenfunktionsprüfung. Urban and Schwarzenberg, Berlin, 1929, p. 489. 